\title{
Performance and Evaluation of Mini Tractor Operated Installer and Retriever of Drip Line
}

\author{
P.R. Balas*, K.B. Jhala, J.M. Makwana and V.V. Agravat
}

Department of Farm Machinery and Power Engineering, College of Agricultural Engineering and Technology, Junagadh Agricultural University, Junagadh, Gujarat, India

*Corresponding author

\section{A B S T R A C T}

\section{Keywords}

Drip irrigation, Drip line,

Drip lateral, Installer,

Retriever, De-coiling,

Handling implement,

Farm equipment, Winder,

Drip tapes

Article Info

Accepted:

10 August 2018

Available Online:

10 September 2018
The developed implement was operated by the mini-tractor using three-point hitch, it performs both the operations of installation and retrieval of drip line. The performance was evaluated on the basis of various field parameters, operating parameters and performance parameters. The experiment was carried out in F-RBD design having two factors and four replications with three different levels of each factor. The factors namely spool rotation (35-53, 53-71 and 71-89 rpm) and forward speed (2.03.0, 3.0-4.0 and 4.0-5.0 kmph) were taken for an experiment. It was observed that the time required for installation and retrieval of drip was 1.0 and $0.94 \mathrm{~s} / \mathrm{m}$ respectively at 71-89 $\mathrm{rpm}$ of spool rotation and $4-5 \mathrm{kmph}$ of forward speed. The fuel consumption in installation and retrieval operations was 4.0 and $4.23 \mathrm{lit} /$ ha respectively at 71-89 $\mathrm{rpm}$ of spool rotation and $4-5 \mathrm{kmph}$ of forward speed. The theoretical field capacity, actual field capacity and efficiency of installation were 1.35 $\mathrm{ha} / \mathrm{h}, 0.85 \mathrm{ha} / \mathrm{h}$ and 63.68 per cent and the same for retrieval were $1.35 \mathrm{ha} / \mathrm{h}, 0.90 \mathrm{ha} / \mathrm{h}$ and 66.66 per cent respectively.

\section{Introduction}

Drip irrigation is the drop by drop application of water directly to roots. It has little or no water losses through conveyance and the onfarm irrigation efficiency of a properly designed and managed drip irrigation system can be as high as 90 per cent, compared with 35 to 40 per cent efficiency of surface method of irrigation (Narayanmoorthy, 1997).

The area covered under drip irrigation systems has, the largest area under drip irrigation include Rajasthan 1.68 Mha, Maharashtra 1.27 Mha, Andhra Pradesh 1.16 Mha, Karnataka
0.85 Mha, Gujarat 0.83 Mha and Haryana 0.57 Mha.

The area under drip irrigation has shown higher growth in recent years, growing at a CAGR (Compound annual growth rate) of 9.85 percent in the 2012-2015 period, while sprinkler irrigation has grown a pace of 6.60 percent in the same time period. Overall, the area under micro-irrigation has grown at a CAGR of 7.97 percent in this time frame (Anon., 2016a).

In field, drip line requires various field operations such as installation and retrieval of 
drip line. Installation and retrieval by mechanical method as well as manual method were used. Farmers have been using manual device for installation and retrieval operation, they were time consuming, laborious, boring, tedious and costly also. These operations need to be done carefully and skilfully to avoid the damages due to folding or twisting of tube during handling and to make the bundle suitable for proper storage.Therefore, the present study was carried out to developed and evaluate the performance of mini-tractor operated installer and retriever of the drip line with the following.

Bida (1998) developed and evaluated the manual lateral coiler and it was observed that the average length of $200 \mathrm{~m}$ lateral recoiled in 3 minutes $20 \mathrm{sec}$ but it was reported that during the coiling the laterals roll over and came out from reel. Also it was stated that the speed of recoiling was constant throughout the length. It was also observed that the average speed of coiling during first 1/3 length of lateral was $0.58 \mathrm{~m} / \mathrm{s}$ and same for the last segment was observed $0.83 \mathrm{~m} / \mathrm{s}$ which is nearly double of the first segment. Zhu et al., (2004) developed a device mounted on a tractor through three-point hitch, which performs both the operations like installation and retrieval in one unit. Speed in both case i.e. installation and retrieval were found to increase as the length of lateral collected/wound on the spool is increased. Karale et al., (2016) observed that the average field efficiency of the tractor operated lateral coiler was $87 \%$ and for manual coiler was found to be $78.26 \%$, whereas in hand coiling it was observed as $63.46 \%$. The cost of coiling operation in tractor operated lateral coiler was observed as ₹ 468/ha where as in manual coiler and hand coiling operations it was found to be ₹ 650/ha and ₹ 1280/ha respectively. Net saving in cost with tractor operated drip lateral coiler was worked out as $28 \%$ and $63.43 \%$ over manual coiler and hand coiling method, respectively. The problem was formulated to minimize time, and easier handling, the research was designed with following objective to evaluate the performance of the mini tractor operated drip line installer and retriever.

\section{Materials and Methods}

A device or mechanism used to install and retrieve a drip line and making bundles can be termed as drip line installer and retriever. Manual drip line retrievers are in use in agriculture. The work of retrieving the line is highly cumbersome and it needs precision or it does not work well with ease while laying down. Also, the time consumed in laying and retrieving the line of whole field can be minimized if some mechanical means / automatic machine are used. The collection and storage of drip lines can also be considered as important operation in maintenance of drip irrigation system. Drip lines are to be removed many times from the field to carry different field operations. A drip line "installer and retriever" was machine which is capable of installing and retrieving drip line in one pass to ensure timeliness in making bundles of drip line. The drip line installer and retriever machine consist of a main frame, hydraulic motor, press wheel, guide wheel, transporting wheel, power transmission system to provide power to installing and retrieving units, and three-point hitch system.

\section{Operating time}

It is the time required to cover test plot of size of $120 \mathrm{~m}^{2}$ with $40 \mathrm{~m}$ length and $3 \mathrm{~m}$ width.

\section{Measurement of spool rotation}

Rotating speed of power transmitting shaft and speed of spool was measured by using digital tachometer. Detailed specifications of digital tachometer are given in appendix VI. 


\section{Machine performance parameters}

\section{Fuel consumption}

The fuel consumption of the tractor while using implement was measured as per the standard method (Mehta et al., 1995).

The fuel measuring device was used to measure the amount of fuel consumed during installation as well as retrieval operation. The device with graduated scales was filled up to the top.

Tractor was kept on level land before use and the initial reading value was recorded. After operation the final reading was recorded.

The difference between these two readings was taken as the amount of fuel consumed by the tractor. Amount of fuel obtained after the test divided by time gives fuel consumption for each test.

\section{Forward speed}

The distance covered divide by time spent to cover that distance give forward speed of the machine. Forward speed was monitored between $2-5 \mathrm{~km} / \mathrm{h}$ during experiment.

Specifications of drip line installer and retriever

The implement operated by 10-20 hp tractor, because implement is semi-mounted no need big category tractor (Table 1).

\section{Experimental design}

The field data were statistically analyzed, using analysis of variance (ANOVA) for the factorial randomized block design (F-RBD) with four replications. The ANOVA procedure was used to evaluate the significance of each parameter and their interactions (Table 2).

\section{Time loss}

The observations on time loss in turning of the tractor as well as adjustment (mounting \& unmounting of drip line bundles) of drip line installer and retriever were recorded.

\section{Turning time}

The time taken in turning at the end of each part of field selected (160 m effective length) was recorded.

Then, the total time loss in turning per unit area was worked out.

\section{Adjustment time}

The time required in adjustment of the device was recorded and reported.

The total time loss per unit area was worked out with the consideration of total event of adjustment in a hectare area.

\section{Field capacity}

Based on time of operation for a particular length of field time lost in turning and adjustment various field capacity were determined for both mechanical as well as manual methods and that too for installation and retrieval separately (Sahay, 2008).

\section{Theoretical field capacity}

Theoretical field capacity can be defined, as coverage of area at operational speed and it depends on width of coverage and speed of operation.

It is calculated by the formula (Kepner et al., 2005), It is calculated by the formula,

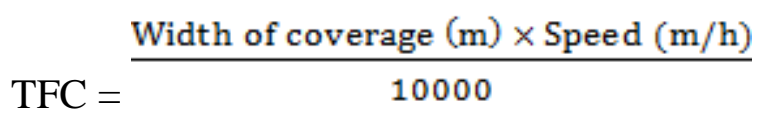




\section{Effective field capacity}

This is the actual rate of field coverage based on field time. This is calculated by measuring area covered by implement and divide by time taken (Kepner et al., 2005). It is calculated by the formula,

EFC

Width of coverage $(\mathrm{m}) \times$ Length of strip $(\mathrm{m})$

Total time taken $\times 10000$

\section{Field efficiency}

Field efficiency is the ratio of effective field capacity to the theoretical field capacity expressed as percentage. The field efficiency of the implement was determined using following formula (Kepner et al., 2005). It is calculated by the formula,

Field efficiency $(\%)=\frac{\text { Effective field capacity }}{\text { Theoretical field capacity }} \times 100$

\section{Results and Discussion}

Tractor operated drip installer and The developed mini-tractor operated installer and retriever is capable of working three rows at a time. The average time in installation and retrieval of $160 \mathrm{~m}$ length drip line were observed 201 and 192 seconds respectively. The theoretical field capacity, actual field capacity and efficiency of installation were $1.35 \mathrm{ha} / \mathrm{h}, 0.85 \mathrm{ha} / \mathrm{h}$ and $63.68 \%$ and the same for retrieval were $1.35 \mathrm{ha} / \mathrm{h}, 0.90 \mathrm{ha} / \mathrm{h}$ and $66.66 \%$ respectively.

\section{Manual installer and retriever}

The manually operated installer and retriever is capable of handling only one row at a time. The average time in installation and retrieval of $160 \mathrm{~m}$ length of drip line were observed 598and 626 seconds respectively. The actual field capacity was observed as 0.28 and 0.27 $\mathrm{ha} / \mathrm{h}$ for installation and retrieval respectively.

\section{Statistical analysis of developed device}

The interaction between spool rotation and forward speed was found significant at 5 per cent level. The spool rotation and forward speed both had significant effect on installation time at 5 per cent level. The minimum value $(1.01 \mathrm{~s} / \mathrm{m})$ of installation time was obtained at 71-89 rpm of spool rotation and 4-5 kmph of forward speed. The maximum value $(1.81 \mathrm{~s} / \mathrm{m})$ of installation time was obtained at $35-53 \mathrm{rpm}$ of spool rotation and 2-3 kmph of forward speed. The mean values of installation time has shown reducing trend with increase in forward speed and spool rotation both.

The interaction between spool rotation and forward speed was found significant at 5 per cent level. The spool rotation and forward speed both had significant effect on installation time at 5 per cent level. The minimum value $(2.88 \mathrm{lit} / \mathrm{ha})$ of fuel consumption was obtained at 35-53 rpm of spool rotation and 2-3 kmph of forward speed while installation. The maximum value (4.0 lit/ha) of fuel consumption was obtained at 71$89 \mathrm{rpm}$ of spool rotation and 4-5 kmph of forward speed.

The mean values of fuel consumption have shown increasing trend with increase in forward speed as well as spool rotation.

The interaction between spool rotation and forward speed was found significant at 5 per cent level. The spool rotation and forward speed both had significant effect on installation time at 5 per cent level. The minimum value $(0.94 \mathrm{~s} / \mathrm{m})$ of retrieval time was obtained at 71-89 rpm of spool rotation and 4-5 kmph of forward speed (Fig. 1-7). 
Table.1 Specifications of drip line installer and retriever

\begin{tabular}{|r|l|l|} 
Sr. No. & \multicolumn{1}{|c|}{ Particulars Details } & \multicolumn{1}{|c}{ Particulars Details } \\
\hline $\mathbf{1}$ & Power source & 15 hp tractor (Mahindra Yuvraj 215) \\
\hline $\mathbf{2}$ & Overall dimension of machine $(\mathrm{L} \times \mathrm{B} \times \mathrm{H}, \mathrm{in} \mathrm{mm})$ & $3800 \mathrm{X} 900 \mathrm{X} 1045$ \\
\hline $\mathbf{3}$ & Weight of machine & 163 \\
\hline $\mathbf{5}$ & Power source for spool rotation & Hydraulic motor \\
\hline $\mathbf{6}$ & No. of spool & 3 \\
\hline $\mathbf{7}$ & Size of shaft & $3800 \mathrm{~mm}$ in length with $45 \mathrm{~mm}$ diameter \\
\hline
\end{tabular}

Table.2 Details of experimental variables

\begin{tabular}{|c|c|c|c|}
\hline Sr. No. & Variables & Parameters & Levels \\
\hline \multirow[t]{2}{*}{1} & \multirow[t]{2}{*}{$\begin{array}{l}\text { Independent } \\
\text { Parameters }\end{array}$} & Spool rotation, SR & $\begin{array}{l}\mathrm{SR} 1=35-53 \mathrm{rpm} \\
\mathrm{SR} 2=53-71 \mathrm{rpm} \\
\mathrm{SR} 3=71-89 \mathrm{rpm}\end{array}$ \\
\hline & & Forward speed, FS & $\begin{array}{l}\mathrm{FS} 1=2.0-3.0 \mathrm{~km} / \mathrm{h} \\
\mathrm{FS} 2=3.0-4.0 \mathrm{~km} / \mathrm{h} \\
\mathrm{FS} 3=4.0-5.0 \mathrm{~km} / \mathrm{h}\end{array}$ \\
\hline 2 & $\begin{array}{l}\text { Dependent } \\
\text { Parameters }\end{array}$ & \multicolumn{2}{|c|}{$\begin{aligned} \text { (a) } & \text { Field parameter } \\
\text { I. } & \text { Installation time }(\mathrm{s} / \mathrm{m}) \\
\text { II. } & \text { Retrieving time }(\mathrm{s} / \mathrm{m}) \\
\text { III. } & \text { Fuel consumption (lit/ha) }\end{aligned}$} \\
\hline
\end{tabular}

Table.3 Effect of interaction of spool rotation and forward speed on installation time $(\mathrm{s} / \mathrm{m})$

\begin{tabular}{|c|c|c|c|}
\hline \multirow{2}{*}{ Spool rotation, rpm } & \multicolumn{3}{|c|}{ Installation time, s/m } \\
\cline { 2 - 4 } & \multicolumn{3}{|c|}{ Forward speed, kmph } \\
\hline $35-53$ & $\mathbf{2 . 0 - 3 . 0}$ & $\mathbf{3 . 0 - 4 . 0}$ & $\mathbf{4 . 0 - 5 . 0}$ \\
\hline $53-71$ & 1.81 & 1.51 & 1.15 \\
\hline $71-89$ & 1.71 & 1.39 & 1.11 \\
\hline SEM 0.57 CD & 1.66 & 1.31 & 1.01 \\
\hline
\end{tabular}

Table.4 Effect of interaction of spool rotation and forward speed on fuel consumption (lit/ha) in case of installation

\begin{tabular}{|c|c|c|c|}
\hline \multirow{2}{*}{ Spool rotation, rpm } & \multicolumn{3}{|c|}{ Fuel consumption, lit/ha } \\
& \multicolumn{3}{|c|}{ Forward speed, kmph } \\
\hline & $\mathbf{2 - 3}$ & $\mathbf{3 - 4}$ & $\mathbf{4 - 5}$ \\
\hline $\mathbf{3 5 - 5 3}$ & 2.88 & 3.03 & 3.05 \\
\hline $\mathbf{5 3 - 7 1}$ & 3.49 & 3.67 & 3.80 \\
\hline $\mathbf{7 1 - 8 9}$ & 3.86 & 3.89 & 4.00 \\
\hline SEM 0.52 CD
\end{tabular}


Table.5 Effect of interaction of spool rotation and forward speed on retrieval time $(\mathrm{s} / \mathrm{m})$

\begin{tabular}{|c|c|c|c|}
\hline Spool rotation, rpm & \multicolumn{3}{|c|}{ Retrieval time, s/m } \\
& \multicolumn{3}{|c|}{ Forward speed, kmph } \\
\hline & $\mathbf{2 - 3}$ & $\mathbf{3 - 4}$ & $\mathbf{4 - 5}$ \\
\hline $\mathbf{3 5 - 5 3}$ & 1.71 & 1.43 & 1.07 \\
\hline $\mathbf{5 3 - 7 1}$ & 1.58 & 1.29 & 1.03 \\
\hline $71-89$ & 1.55 & 1.19 & 0.94 \\
\hline SEM 1.09 $\mathrm{CD}_{0.05} 3.18$ & & & \\
\hline
\end{tabular}

Table.6 Effect of interaction of forward speed and conveyor speed on fuel consumption (lit/ha) in case of retrieval

\begin{tabular}{|c|c|c|c|}
\hline \multirow{2}{*}{ Spool rotation, rpm } & \multicolumn{3}{|c|}{ Fuel consumption, lit/ha } \\
& \multicolumn{3}{|c|}{ Forward speed, kmph } \\
\hline $\mathbf{3 5 - 5 3}$ & $\mathbf{2 - 3}$ & $\mathbf{3 - 4}$ & $\mathbf{4 - 5}$ \\
\hline $\mathbf{5 3 - 7 1}$ & 3.25 & 3.26 & 3.46 \\
\hline $\mathbf{7 1 - 8 9}$ & 3.63 & 3.94 & 4.22 \\
\hline SEM 1.02 CD & 4.18 & 4.21 & 4.23 \\
\hline
\end{tabular}

Fig.1 Drip line installer and retriever

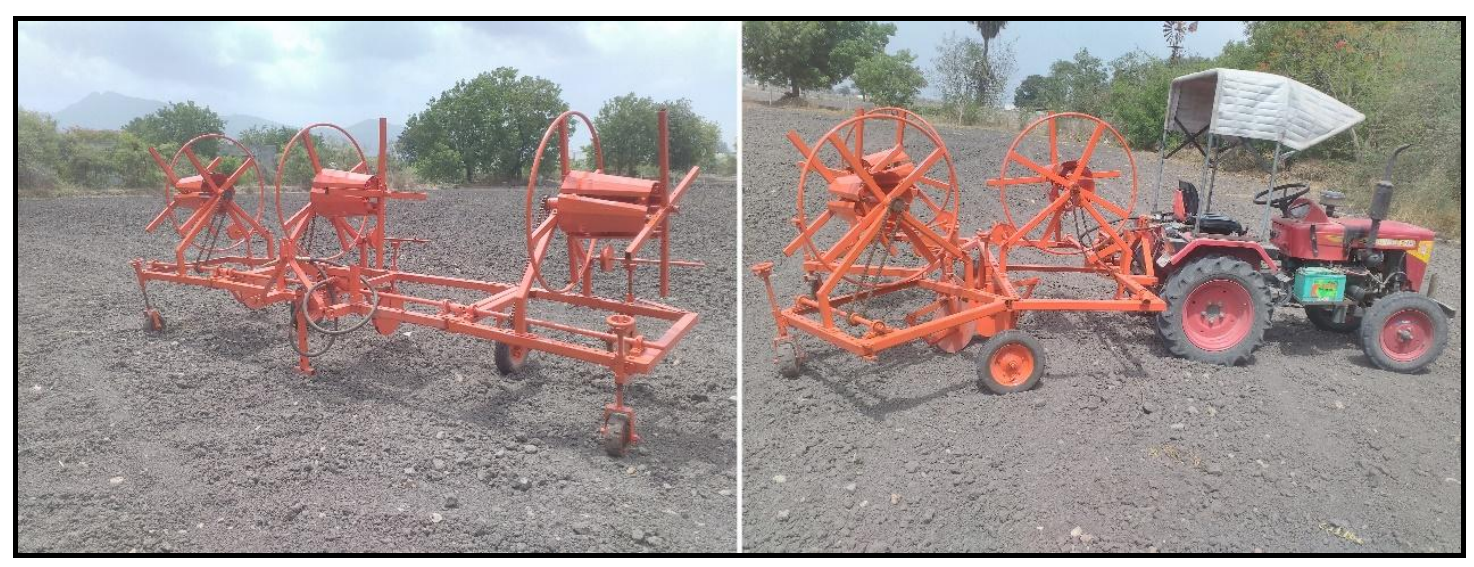

Fig.2 Tachometer for measurement of RPM

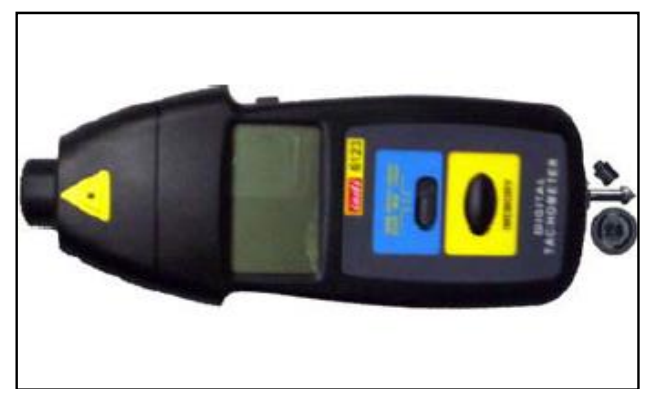


Fig.3 Mini tractor operated installer and retriever of drip line

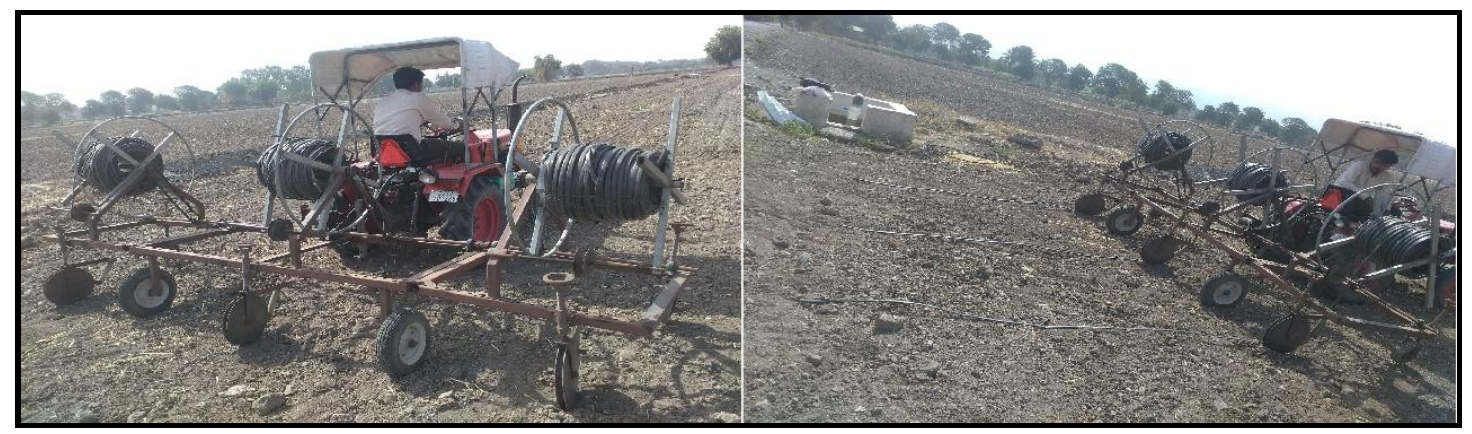

Fig.4 Effect of forward speed on installation time at different spool rotations

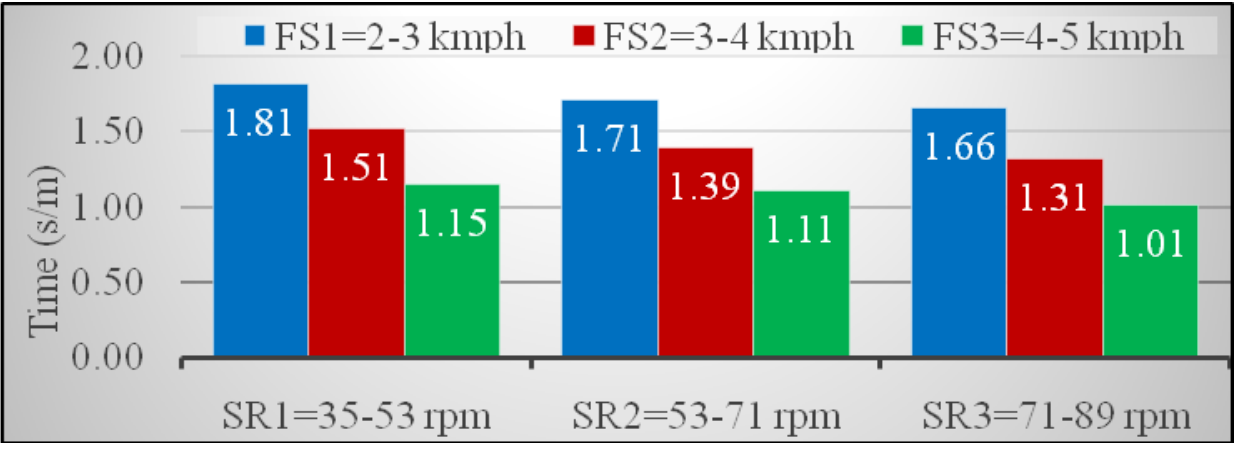

Fig.5 Effect of forward speed on fuel consumption at different spool rotations

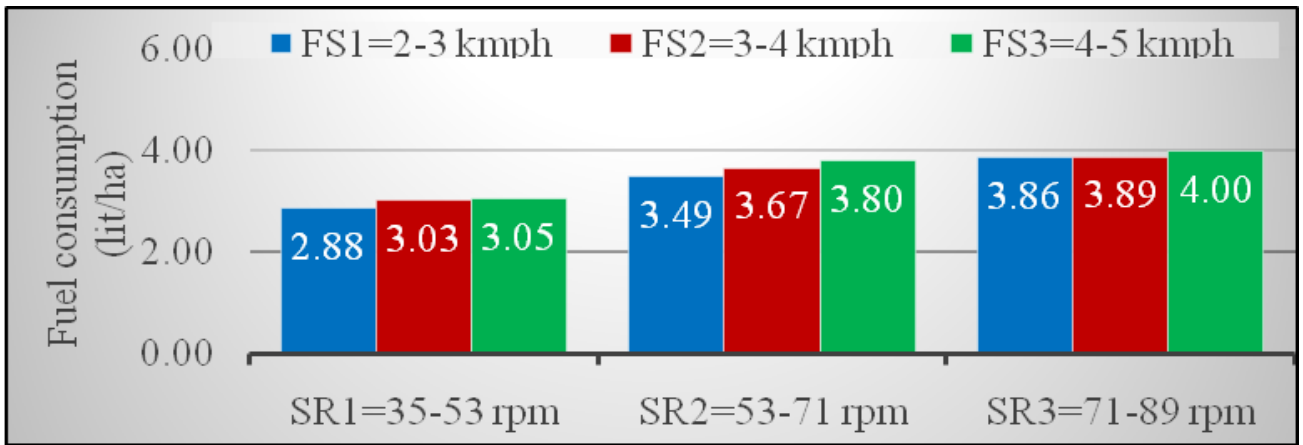

Fig.6 Effect of forward speed on retrieval time at different spool rotations

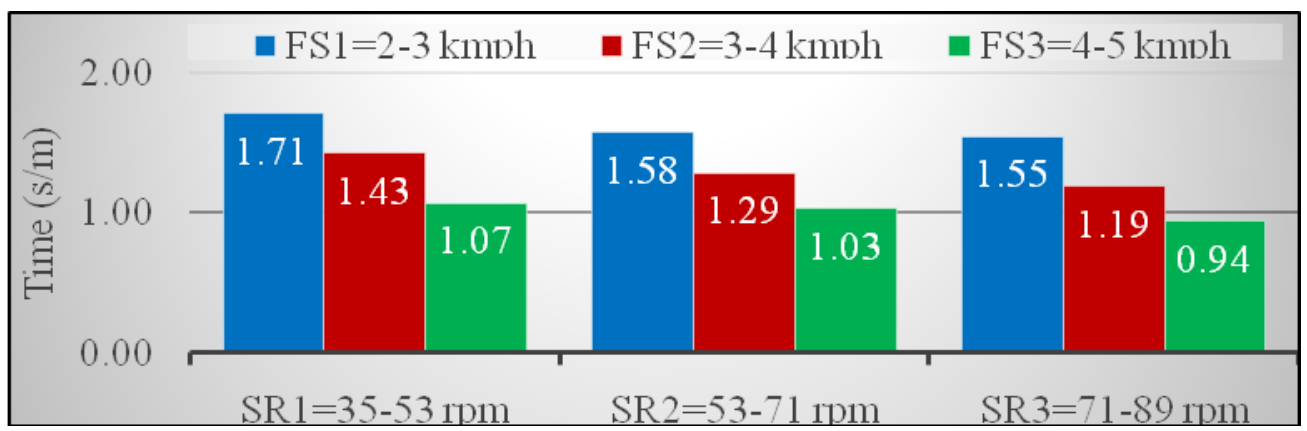


Fig.7 Effect of forward speed on fuel consumption at different spool rotations

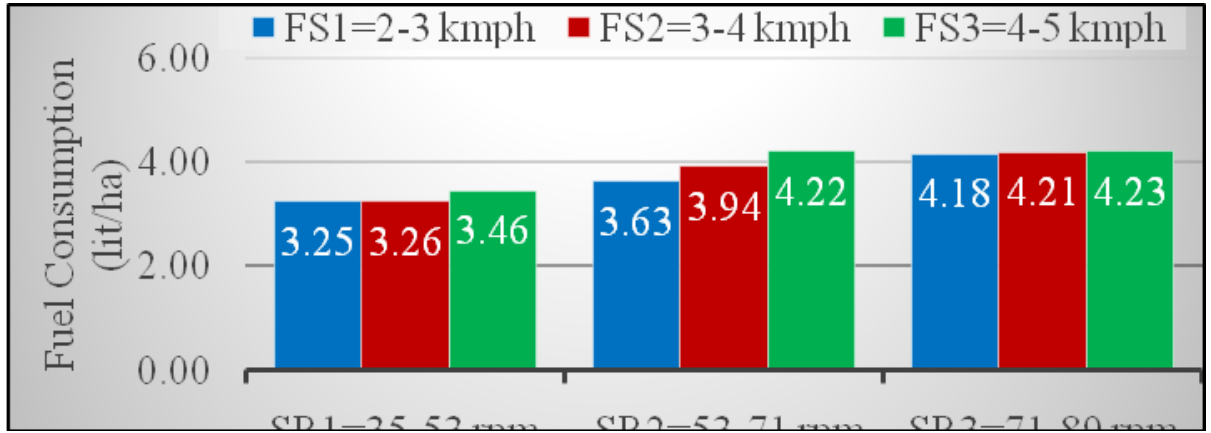

The maximum value $(1.71 \mathrm{~s} / \mathrm{m})$ of retrieval time was obtained at $35-53 \mathrm{rpm}$ of spool rotation and 2-3 kmph of forward speed.

The mean values of retrieval time has shown reducing trend with increase in forward speed and spool rotation both.

The interaction between spool rotation and forward speed was found significant at 5 per cent level. The spool rotation and forward speed both had significant effect on installation time at 5 per cent level.

The minimum value (3.25 lit/ha) of fuel consumption was obtained at 35-53 rpm of spool rotation and $2-3 \mathrm{kmph}$ of forward speed. The maximum value (4.23 lit/ha) of fuel consumption was obtained at 71-89 rpm of spool rotation and $4-5 \mathrm{kmph}$ of forward speed.

The mean values of fuel consumption has shown increasing trend with increase in forward speed as well as spool rotation.

Theoretical field capacity of the installer retriever of drip line was $1.35 \mathrm{ha} / \mathrm{h}$ for both installation and retriever of drip line.

The effective field capacity of the installer and retriever were 0.85 and $0.90 \mathrm{ha} / \mathrm{h}$ respectively. The field efficiency of the installer and retriever of drip line were 63.68 $\%$ and $66.66 \%$ respectively.
The mean values of installation time and retrieval time has shown reducing trend with increase in forward speed and spool rotation both.

The mean values of fuel consumption in case of installation and retrieval has shown increasing trend with increase in forward speed as well as spool rotation.

The theoretical field capacity, actual field capacity and efficiency of installation were $1.35 \mathrm{ha} / \mathrm{h}, 0.85 \mathrm{ha} / \mathrm{h}$ and $63.68 \%$ and the same as for retrieval were $1.35 \mathrm{ha} / \mathrm{h}, 0.90 \mathrm{ha} / \mathrm{h}$ and $66.66 \%$ respectively.

\section{References}

Bida, H. D. (1998). Thesis of design, fabrication and testing of de-coiler for drip laterals. (Unpublished B.Tech Thesis), Dr.Panjabrao Deshmukh Krishi Vidyapeeth, Akola, India.

Coates, W. E. 1985. Comparison of equipment for the installation and retrieval of drip irrigation laterals. Transactions of the ASAE. 28(4): 11731177.

Coates, W. E. 1986a. A reel braking system for drip lateral handling equipment. ASAE Applied Engineering in Agriculture. 2(2): 101-103.

Coates, W. E. 1986b. An implement for handling drip Irrigation laterals. $A S A E$ 
Applied Engineering in Agriculture. 2(2): 144-147.

Coates, W. E. and Lorene, B. R. 1987. A device for installing subsurface trickle irrigation laterals. ASAE Applied Engineering in Agriculture. 3(1): 57-58.

Indian Standard (1964-1967). Test code for estimating cost of farm machinery.

Indian Standard (9164 - 1979). Guide for estimating cost of farm machinery operation.

Karale, D.S., Kankal, U.S. and Khambalkar, V.P. 2016. Performance Evaluation of Tractor drawn Drip Lateral Coiler. Amity Journal of Agribusiness 1(1): (45-53)

Kepner, R. A., Bainer, R. and Barger, E. L. 2005. Principles of Farm Machinery. Ch. 5. CBS Publishing Company, New Delhi, India.

Narayanamoorthy, A. 1997. Economic viability of drip irrigation: An empirical analysis from Maharashtra. Indian Journal of Agricultural Economics. 52(4): 728-739.

Narayanmoorthy, A. 2004. Drip and sprinkler irrigation in India: Benefits, potential and future directions. Water Policy. 26(1): 253-265.
Narayanmoorthy, A. 2010. Economics of drip irrigated cotton: A synthesis of four case studies. Indian Journal of Agricultural Economics. 58(4): 37-50.

Sahay, J. 2008. Elements of Agricultural Engineering, Standard Publishers Distribution, New Delhi, pp: 234.

Shukla, S. 2018. Thesis of design, development and performance evaluation of groundnut port collector, (Unpublished ph.d Thesis), College of Agricultural Engineering \& technology, Junagadh, India.

Taley, S. S., Bhende. S. M., \& Tale, V. P. (2006). Testing, evaluation and modification of manual coler for drip lateral. $A M A, 37(1)$ : 75-79

Umar, B. 2003. Comparison of manual and manual-cum-mechanical energy uses in groundnut production in a semi-arid environment. Agricultural Engineering International: The CIGR E-journal, Manuscript EE03 003 (V).

Zhu, H., Butts, C. L., Lamb, M. C. and Blankenship, P. D. 2004. An implement to install and retrieve surface irrigation laterals. Applied Engineering in Agriculture. 20(1): 17-23.

\section{How to cite this article:}

Balas, P.R., K.B. Jhala, J.M. Makwana and Agravat, V.V. 2018. Performance and Evaluation of Mini Tractor Operated Installer and Retriever of Drip Line. Int.J.Curr.Microbiol.App.Sci. 7(09): 1362-1370. doi: https://doi.org/10.20546/ijcmas.2018.709.163 